\title{
Early Permian glacio-marine thecamoebian assemblages from the northwest Himalayas, India
}

\author{
ARUN KUMAR ${ }^{1, *}$, ANJUM FAROOQUI ${ }^{2} \&$ NEERJA JHA ${ }^{2}$ \\ ${ }^{1}$ Center for Petroleum and Minerals, Research Institute, King Fahd University of Petroleum and Minerals, Dhahran 31261, Saudi Arabia \\ ${ }^{2}$ Birbal Sahni Institute of Palaeobotany 53 University Road, Lucknow 226007, India \\ *Corresponding author (e-mail: arunkumarlko@hotmail.com)
}

\begin{abstract}
Diverse assemblages of thecamoebians are reported here from the Early Permian Manjir Formation of the northwest Himalaya in India. These thecamoebian tests were found in palynological preparations and are assigned an Early Permian age based on co-occurrence of age-diagnostic palynomorphs. Several of them show very close morphological affinity with extant thecamoebian genera, such as Amphitrema, Arcella, Centropyxis, Cyclopyxis, Cucurbitella, Difflugia and Trinema. This fauna lived in shallow-marine environments during the Early Permian deglacial phase of the widespread Late Carboniferous-Early Permian glaciation of Gondwana. The extant forms used for morphological comparison with the fossil forms were recorded from lakes and ponds in various parts of India. This study supports the current hypothesis of minimal evolution in thecamoebian lineages through geological time, and this group of protists has survived through long geological time and several mass extinction events without any significant morphological change. Stratigraphical and palaeontological evidence indicates that this fauna lived in the shallow-marine environments along the northwestern margin of Indian Gondwana during the deglacial phase of Late Carboniferous-Early Permian glaciation. J. Micropalaeontol. 30(1): 75-89, May 2011.
\end{abstract}

KEYWORDS: Permian, glaciomarine, thecamoebians, Himalayas, India

\section{INTRODUCTION}

Thecamoebians characterize a special group of testate protists (agglutinated or autogenous) which belong to the Subphylum Sarcodina (Medioli \& Scott, 1988). These are an important component of aquatic and terrestrial ecosystems and also occur in marginally brackish environments (Charman et al., 2000; Patterson \& Kumar, 2002). They are characterized by a sac/ cap-like test, with a simple aperture known as a pseudostome through which extrude pseudopods of the amoeba dwelling inside it. They are consumers of bacteria, fungi and different algal groups and are thus important for the energy flow and nutrient cycles in these ecosystems (Medioli \& Scott, 1983, 1988; Beyens \& Meisterfeld, 2002). Most of the known fossil thecamoebians are agglutinated by calcareous or siliceous grains and/or diatom frustules (Medioli et al., 1990a, b). They are known from lake sediments from the tropics to the Arctic (see references in Patterson \& Kumar, 2002; Boudreau et al., 2005), peat bogs (Woodland et al., 1998; Charman et al., 2000) and salt marshes (Charman et al., 2002; Roe et al., 2002; Riveiros et al., 2007). Published thecamoebian studies are mainly from the lakes and bogs in Europe and North America and there are relatively fewer thecamoebian studies from the tropical regions (Hoogenraad \& Groot, 1940, 1946; van Oye, 1949; Sudzuki, 1979; Dalby et al., 2000; Roe \& Patterson, 2006; Farooqui \& Gaur, 2007). Some of the earliest thecamoebian studies from India include brackish-water lakes and ponds of nineteenthcentury Mumbai (Carter, 1856, 1864).

\section{PRE-QUATERNARY OCCURRENCES OF THECAMOEBIANS}

Distribution of fossil thecamoebian tests ranges from the Neoproterozoic through to the Holocene but their occurrence is patchy with wide gaps in the fossil record. The oldest undisputed record of thecamoebians is described as vase-shape microfossils (VSMs) from the Neoproterozoic rocks of Grand Canyon,
USA by Porter \& Knoll (2000) and Porter et al. (2003). A diverse group of vasiform forms is known from Neoproterozoic sediments from various parts of the world, and a critical morphological evaluation about their possible affinity with thecamoebians is provided by Porter \& Knoll (2000). Wellpreserved and diverse VSMs were reported from carbonate nodules in $>742 \pm 6 \mathrm{Ma}$ old black shales of the Chuar Group, Grand Canyon, USA, and nine new species belonging to eight new genera were described by Porter et al. (2003) using the taxonomy of modern testate amoebae. This assemblage also includes eight species belonging to two genera already known.

Medioli et al. (1990a) critically reviewed reports of preQuaternary thecamoebians published between 1930 and 1990. These included 26 species of agglutinated forms whose thecamoebian affinity was questioned. The oldest Phanerozoic record of thecamoebians is from Cambrian organic residues from Nova Scotia, Canada (Scott et al., 2003). Other Palaeozoic finds are from the Carboniferous (Vasicek \& Ruzicka, 1957; Wightman et al., 1994; Wolf, 1995) and a short report on Early Permian material of the Himalayas of India (Farooqui et al., 2010). The present paper is an expanded version of Farooqui et al. (2010), which discusses the geological and evolutionary significance of the reported assemblages. Reports of thecamoebians from the Mesozoic include forms isolated from amber and sediments reported by Schönborn et al. (1999), Poinar et al. (1993), Medioli et al. (1990b), Waggoner (1996a), Schmidt et al. (2001, 2004), van Hengstum et al. (2007), Bassi et al. (2008) and Martin-González et al. (2009). There are also a few scattered reports of Tertiary thecamoebians (Bradley, 1931; Frenguelli, 1933; Kövàry, 1956; Waggoner, 1996b; Schiller, 1997, 1998, 1999; Boeuf \& Gilbert, 1997; Foissner \& Schiller, 2001).

Patterson \& Kumar $(2000,2002)$ and Schmidt et al. (2004) have summarized fossil records and evolutionary history of the Testate Amoebae. More recently, van Hengstum et al. (2007) provided a stratigraphical summary of the distribution of 


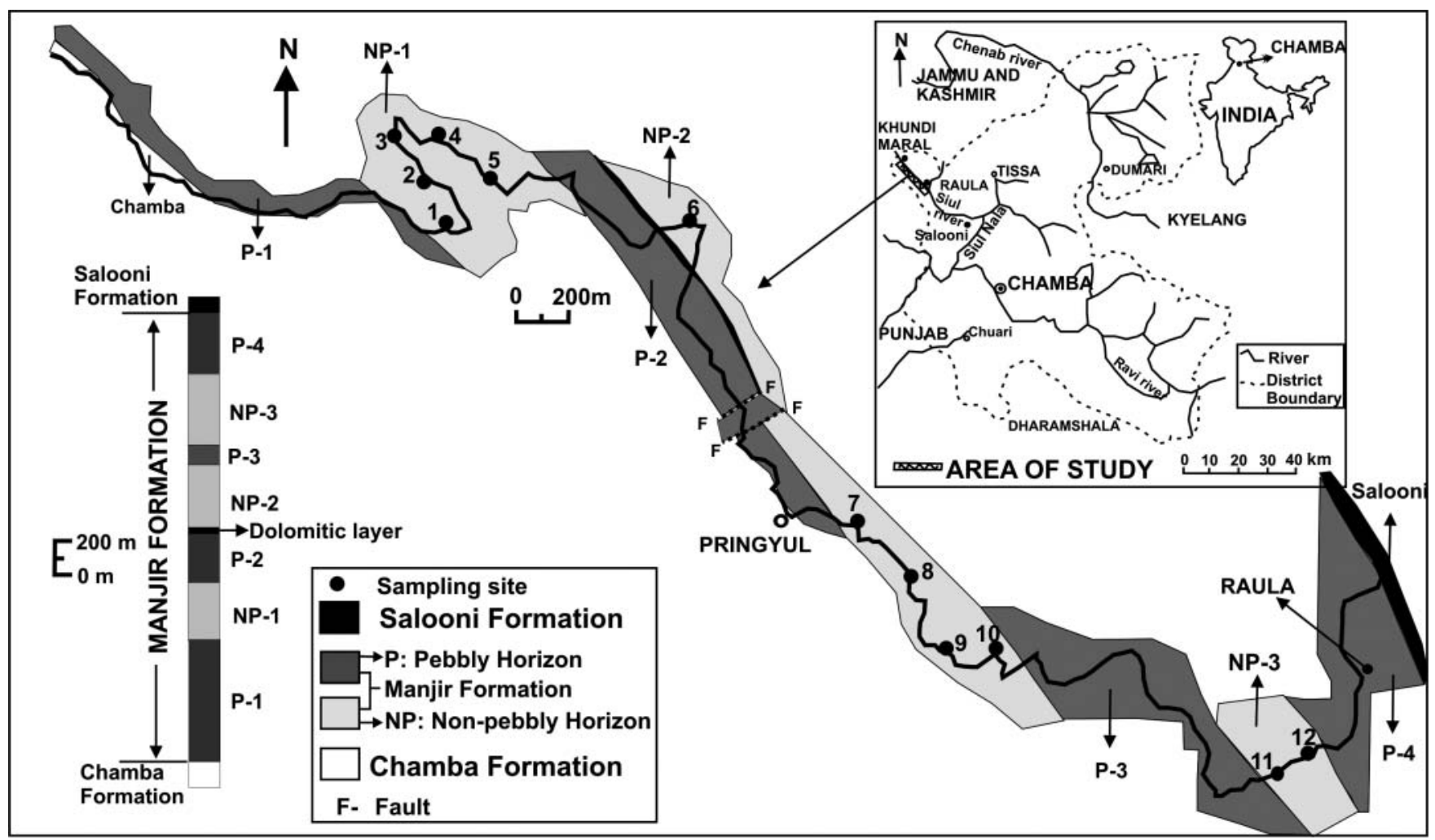

Fig. 1. Location map of the Khundi-Maral-Raula section in Chamba District, Himachal Pradesh, India.

thecamoebian families. These studies clearly demonstrate that despite a long geological history, thecamoebian lineages as seen in their test morphology have shown minimal evolution and display close resemblance to their Holocene forms.

\section{THECAMOEBIANS IN PALYNOLOGICAL PREPARATIONS}

Since thecamoebian tests are secreted (autogenous) and are proteinaceous, they are acid-resistant and have been reported in palynological preparations by Kumar \& Patterson (2002), Farooqui \& Gaur (2007) and Farooqui et al. (2010) plus in many other publications. Srivastava \& Bhattacharya (1998) reported an assemblage of Early Permian age palynomorphs from coal balls of Arunachal Pradesh, northeastern Himalayas, India. A specimen referred to as '?Chitinozoa like vesicle' (their pl. 1, fig. 11) is most likely a specimen of Difflugia. Likewise, Pande et al. (2004) published a palynomorph assemblage from the Manjir Formation (Early Permian) of Himachal Pradesh in north India. They too reported an 'unidentified specimen' (their pl. 2, fig. 6), which is a well-preserved specimen of Centropyxis. There are significant opportunities for discovering thecamoebian assemblages from Phanerozoic sediments world-wide that may occur in palynological preparations (Kumar, 2011). The present paper also deals with Permian thecamoebians observed in palynological preparations. This method was applied in the present study because samples from the Manjir Formation are hard sedimentary rocks, and acid treatment was essential for retrieving the palynomorphs and other organic matter embedded within them.

\section{STRATIGRAPHY AND AGE}

The Chamba Basin (Himachal Pradesh) (Fig. 1) represents the Tethyan realm in the northwest Himalayas and the Manjir Formation is a major stratigraphic unit of this basin. Lithologically the Manjir Formation includes both arenaceous and calcareous rocks that are foliated, moderately metamorphosed and are represented by heterogeneous, poorly sorted pebbly horizons separated by non-pebbly horizons (diamictites). The section of the Manjir Formation studied constitutes three nonpebbly units (NP-1, NP-2 and NP-3) separated by four pebbly units (P-1, P-2, P-3 and P-4). Samples for the present study were collected from the dark grey to black shale/slate units of the non-pebbly horizons. The Manjir Formation is overlain by the Salooni Formation and underlain by the Chamba Formation (Table 1). Most early work on the geology of this region considered the Manjir Formation to be of Late Proterozoic age on the basis of its lithology and regional stratigraphy (Sehgal, 1965; Rattan, 1973). Later, well-preserved and stratigraphically significant palynomorphs were discovered from this formation. A rich assemblage of palynomorphs dominated by monosaccate pollen Barakarites, Parasaccites and Plicatipollenites, some nonstriate disaccates Scheuringipollenites, Platysaccus and striate disaccates Striatopodocarpites, Faunipollenites and Striatites gave a definite Early Permian age to the Manjir Formation (Pande et al., 2004).

Some samples from the pebbly units were also macerated for thecamoebians but were found to be barren. The present study is based on twelve samples that were collected along the Khundi-Maral-Raula section along the Siul River (Fig. 1). 


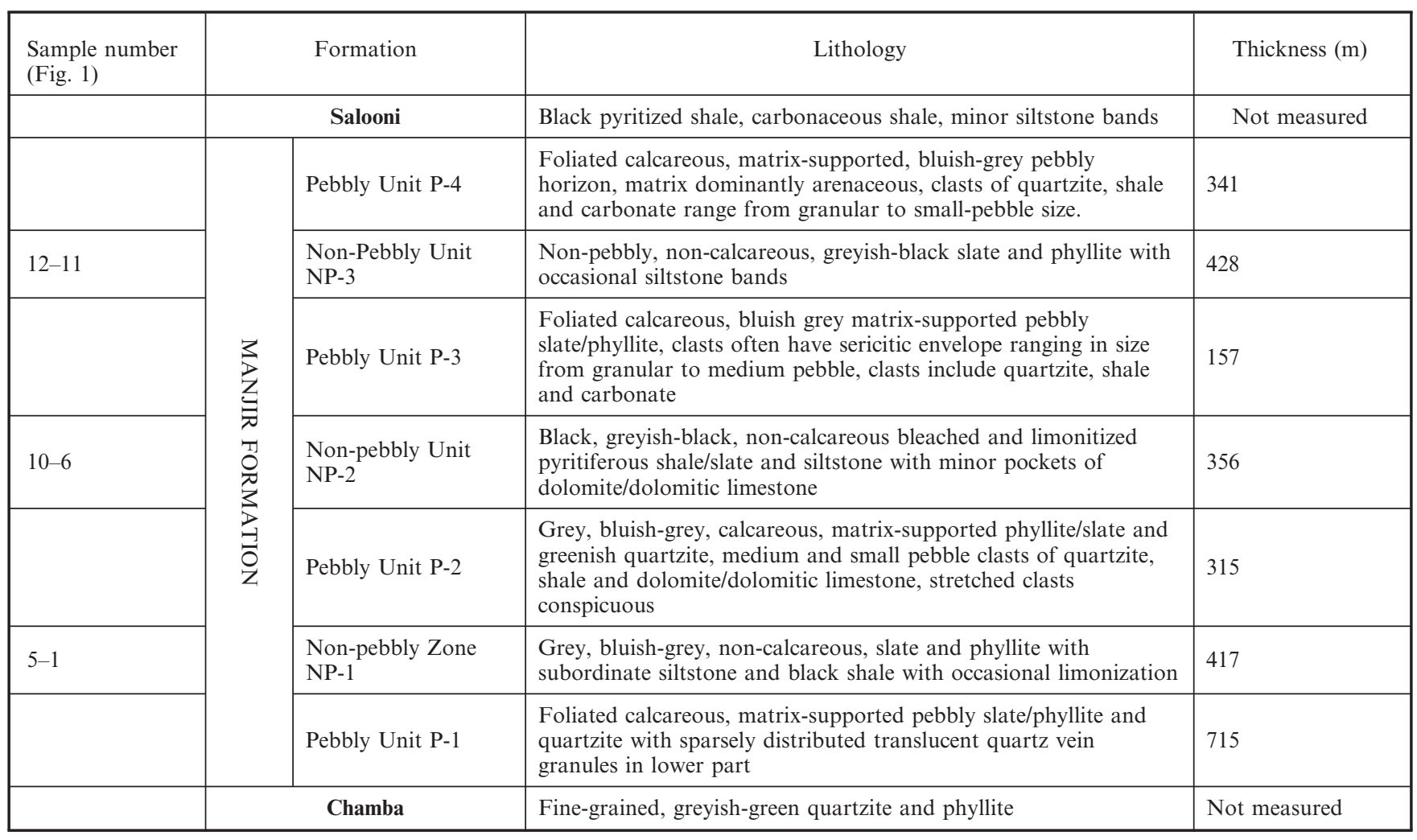

Table 1. Lithostratigraphy of the Manjir Formation along the Khundi-Maral-Raula section (Siul River) in Chamba District, Himachal Pradesh, India.

The detailed regional lithostratigraphy and thicknesses of four pebbly and three non-pebbly horizons are given in Table 1.

\section{MATERIAL AND METHODS}

A total of 12 samples, five each from NP-1 and NP-2, and two from NP-3 were studied (Fig. 1). Testate amoebae were isolated from the shale/slate samples after treatment with hydrochloric acid $(\mathrm{HCl})$, generally used for isolating palynomorphs from hard calcareous sediments. After washing out the acid, the samples were sieved through 600 mesh $(>15 \mu \mathrm{m})$ and the residue of the larger fraction was mounted on glass slides in glycerol. The slides were scanned for thecamoebians under a high-power light microscope (Olympus BX-52). The identifications are based on Medioli \& Scott (1983), Kumar \& Dalby (1998) and Beyens \& Meisterfeld (2002).

For the purposes of identification of Manjir Formation thecamoebians, and to compare their morphological affinities with extant thecamoebians, several modern lake/pond sediments were also studied from various parts of India. Sediment-water interface samples were collected mainly from the periphery of the lakes/ponds. Some $10 \mathrm{~g}$ of air-dried sediment was warmed in $5 \%$ potassium hydroxide $(\mathrm{KOH})$ to remove organic matter coagulation. After sieving through a 150 mesh $(\sim 105 \mu \mathrm{m})$, the filtrate was kept overnight and the supernatant was decanted. The residue was acetolysed (Erdtman, 1943) in order to study the slides under a high-power light microscope.

\section{RESULTS}

The three non-pebbly units NP-1, NP-2 and NP-3 yielded fairly good assemblages of thecamoebian tests (Pls 1-6) as well as characteristic Early Permian palynomorphs (Pl. 7). Plates 1 and 2 show co-occurrences of various age-diagnostic Early Permian palynomorphs and thecamoebians in the same field-of-view, thus authenticating the presence and age of thecamoebians in the Manjor Formation. The total counts of the thecamoebians recovered in $10 \mathrm{~g}$ samples are given for all the 12 samples in Figure 2. The preservation of these tests is good enough to study their basic morphology and identification. Although the Manjir Formation thecamoebian assemblages are of Early Permian age, most of them demonstrate very close morphological similarity with extant forms even at the strain level (Reinhardt et al., 1998). Several of them look almost identical to the forms recovered from modern lakes in India. We have demonstrated this fact by placing several fossil forms beside extant ones in Plates 4-6. We faced a dilemma about naming them, whether to propose new names for these microfossils or assign them names of Holocene thecamoebians. Since it was possible to identify $\sim 300 \mathrm{Ma}$ old forms with extant ones we decided to use current nomenclature rather than giving them new names. We believe giving new names would have created nomenclatural confusion for almost identical forms. The characteristics of the assemblages are as follows.

\section{NP-1}

This lithological unit overlies the pebbly unit P-1 and is characterized by grey to bluish-grey, non-calcareous, slate and phyllite 


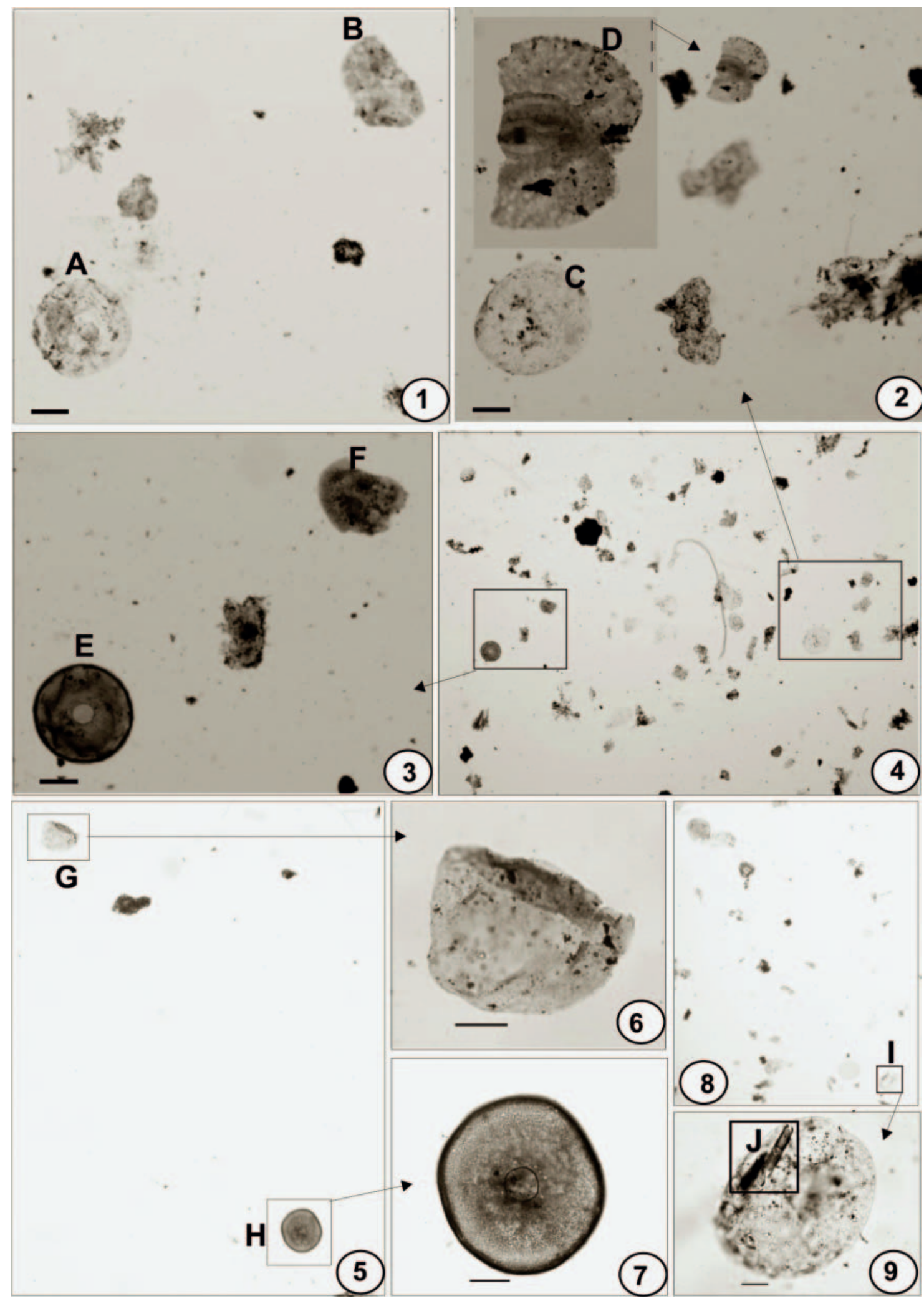

Explanation of Plate 1.

fig. 1. cf. Trigonopyxis sp. (A) and Scheuringipollenites maximus (J45/4) (B), slide no. 12865A. fig. 2. Centropyxis arcelloides (C) and Primuspollenites sp. (D), slide no. 12865A. fig. 3. Arcella artocrea (G25/3) (E) and Scheuringipollinites sp. (F). fig. 4. A view showing both pollen and thecamoebians together in a slide. fig. 5. Pollen $(\mathrm{G})$ and thecamoebian $(\mathrm{H})$, slide no. 12865. fig. 6. Faunipollenites sp. fig. 7. Arcella artocrea (G29/3). figs 8, 9. Centropyxis aculeata 'aculeata': (I) and showing diatom frustules (J) (G25/3), slide no. 13964. All slides are housed in the Birbal Sahni Institue of Palaeobotany, Lucknow. England Finder coordinates in brackets. Scale $20 \mu \mathrm{m}$. 

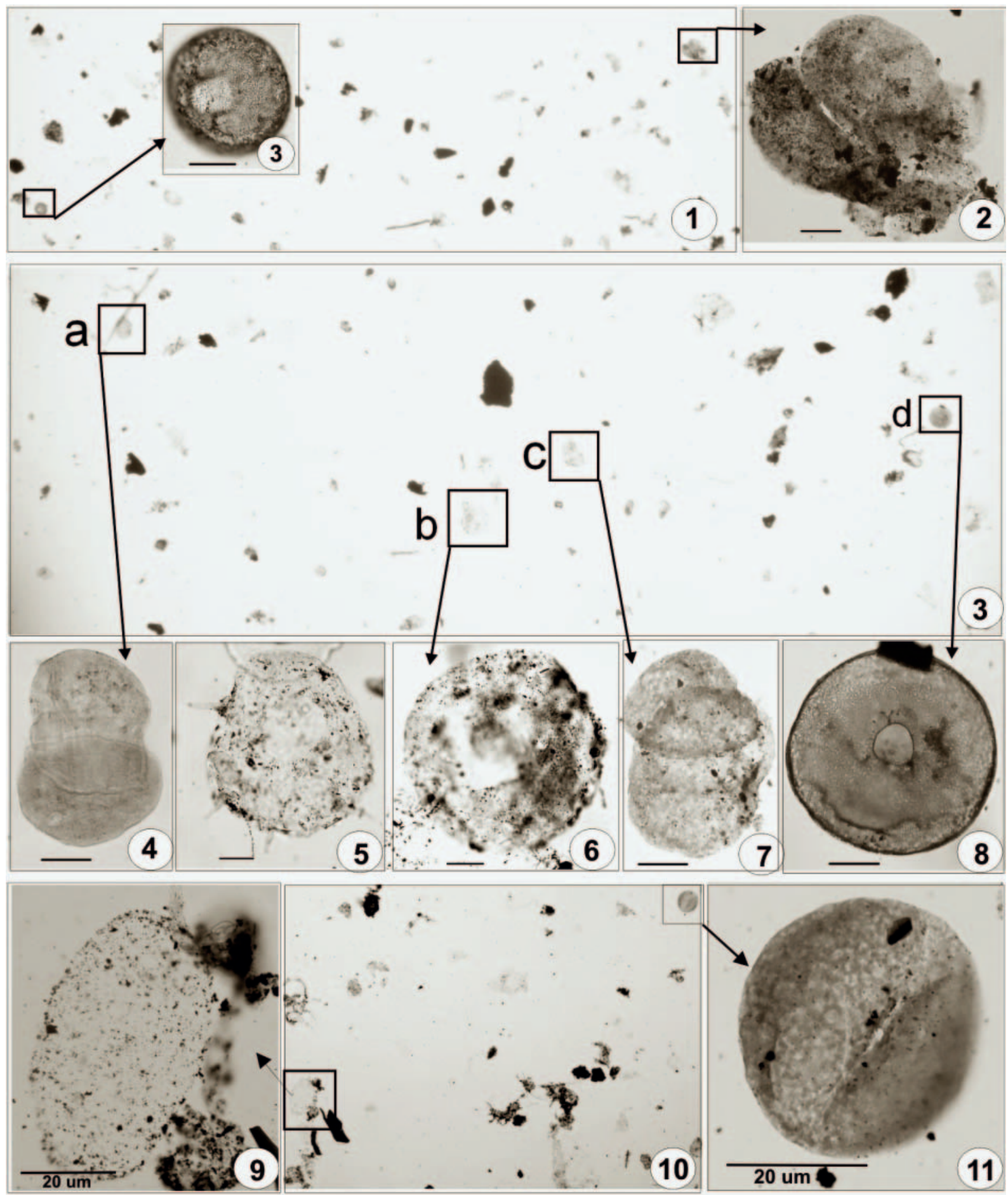

Explanation of Plate 2.

fig. 1. Pollen and thecamoebian (Arcella 3) in slide no. 12865A. figs 2, 7, 11. Scheuringipollenites sp.: 2, (M22/5); 7, (L43/3). fig. 3. Pollen and thecamoebians in slide no. 12865A. fig. 4. Faunipollenites (L33/3), slide no. 12865A. fig. 5. Centropyxis aculeata 'aculeata' (F26/4), no. slide 12865A (not in view of fig. 3). fig. 6. Centropyxis sp. (L42/4). fig. 8. Arcella artocrea (M43/1). fig. 9. Amphitrema flavum (N22/5), slide no. 13956. fig. 10. Amphitrema sp. and Scheuringipollenites sp. in low power. All slides are housed in the Birbal Sahni Institue of Palaeobotany, Lucknow. England Finder coordinates in brackets. Scale $20 \mu \mathrm{m}$. 


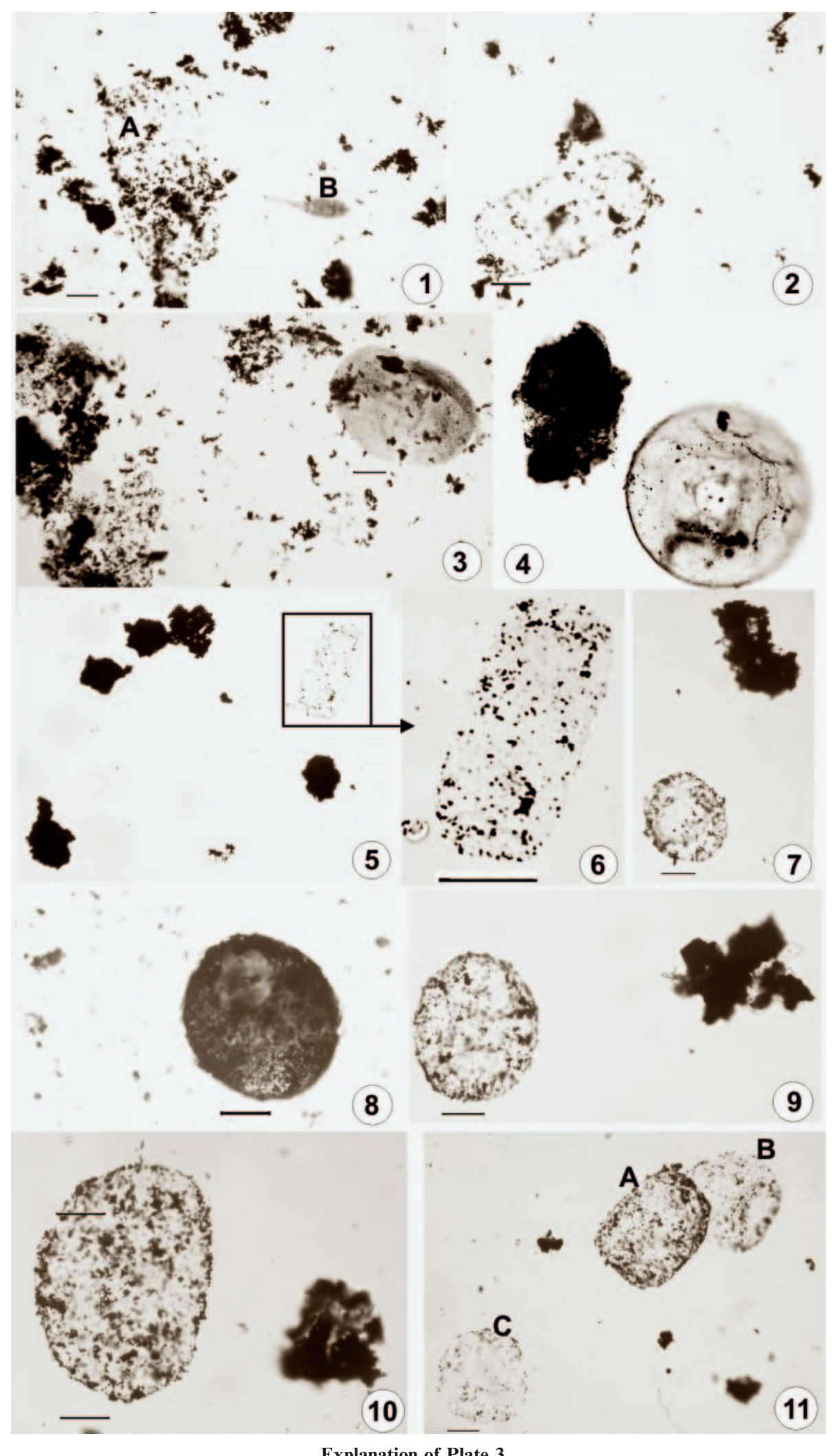

Explanation of Plate 3.

fig. 1. Dispersed organic matter in slide no. 13956: Amphitrema flavum (A) and fungal spore (B). figs 2, 5, 6. Amphitrema flavum: 2 (G34/2); 5, 6 (J35/2), slide no. 13966. fig. 3. Arcella sp. (N21/2), slide no. 13965. fig. 4. Arcella gibbosa (P21/2), slide no. 12861. fig. 7. Arcella megastoma (K33/1), slide no. 13966. fig. 8. Difflugia gramen (F35/2), slide no. 13959. fig. 9. Centropyxis sp. (L42/2), slide no. 13962. fig. 10. Centropyxis aerophila (G21/1), slide no. 13965. fig. 11. Difflugia penardi (A), cf. Cyclopyxis kahlii (B) and Arcella megastoma (F32/1) (C), slide no. 13960. All slides are housed in the Birbal Sahni Institue of Palaeobotany, Lucknow. England Finder coordinates in brackets. Scale is $20 \mu \mathrm{m}$. 

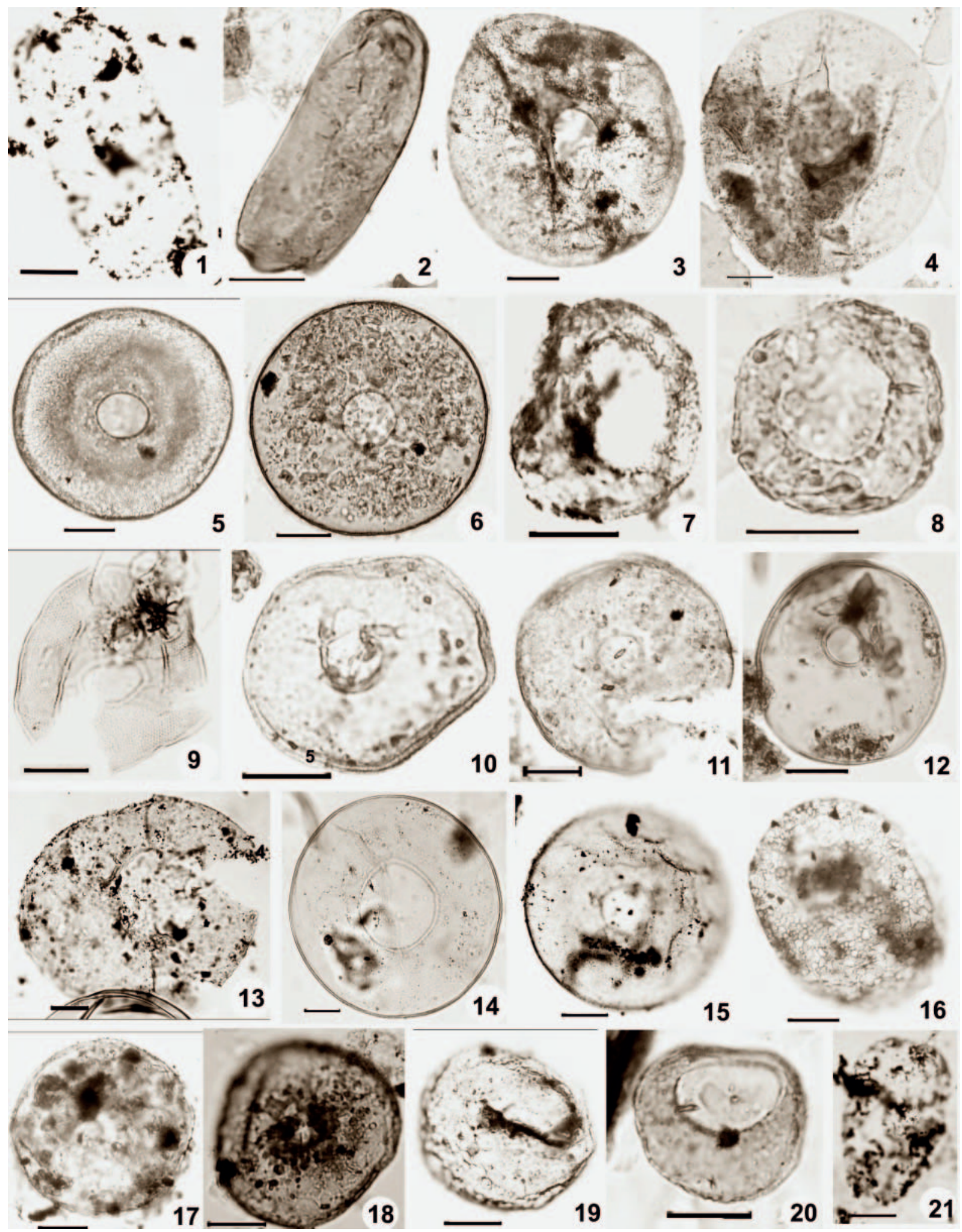

Explanation of Plate 4.

figs 1, 2. Amphitrema flavum: 1, fossil (G34/2), slide no. 13956; 2, Recent, source - fresh water, Sadatal lake, India. figs 3, 4. Arcella arenaria: 3, fossil (U30/1), slide no. 12865A; 4, Recent, source - mouth Godavari River, Andhra Pradesh, India. figs 5, 6. A. artocrea: 5, fossil (Q35 \& Q35/1), slide no. 12865A; 6, Recent, source - coastal wetland, Pichavaram, Tamil Nadu, India. figs 7, 8. A. megastoma: 7, fossil (T30/3), slide no. 12865; 8, Recent, sources - fresh-water lakes, coastal wetlands, mouth of the rivers, sewage drainage system, India. figs 9-12. A. discoides: 9, fossil (W38/2), slide no. 12861; 10, Recent, source - Bet Dwarka, archaeological site, Gujarat, India; 11, fossil (V22/1), slide no. 13963; 12, Recent, source - Nilarevu mouth, Godavari River, India. figs 13, 14. A. vulgaris: 13, fossil (W20/3), slide no. 13964; 14, Recent, source - Sadatal lake, India. fig. 15. cf. A. gibbosa (fossil) (P21/2), slide no. 12861. fig. 16. cf. Centropyxis hirsuta (fossil) (U22/1), slide no. 13960. figs 17, 18. cf. Trigonopyxis arcula: 17, fossil (S12/3), slide no. 13958B; 18, Recent, sources - coastal wetland, river mouths, east coast, India. figs 19, 20. Cyclopyxis sp.: 19, fossil (P36/4), slide no. 13957; 20, Recent, source - Nilarevu mouth, Godavari River, India. fig. 21. Trinema sp. (fossil) (Q38/1), slide no. 13960. All slides are housed in the Birbal Sahni Institue of Palaeobotany, Lucknow. England Finder coordinates in brackets. Scale $20 \mu \mathrm{m}$. 


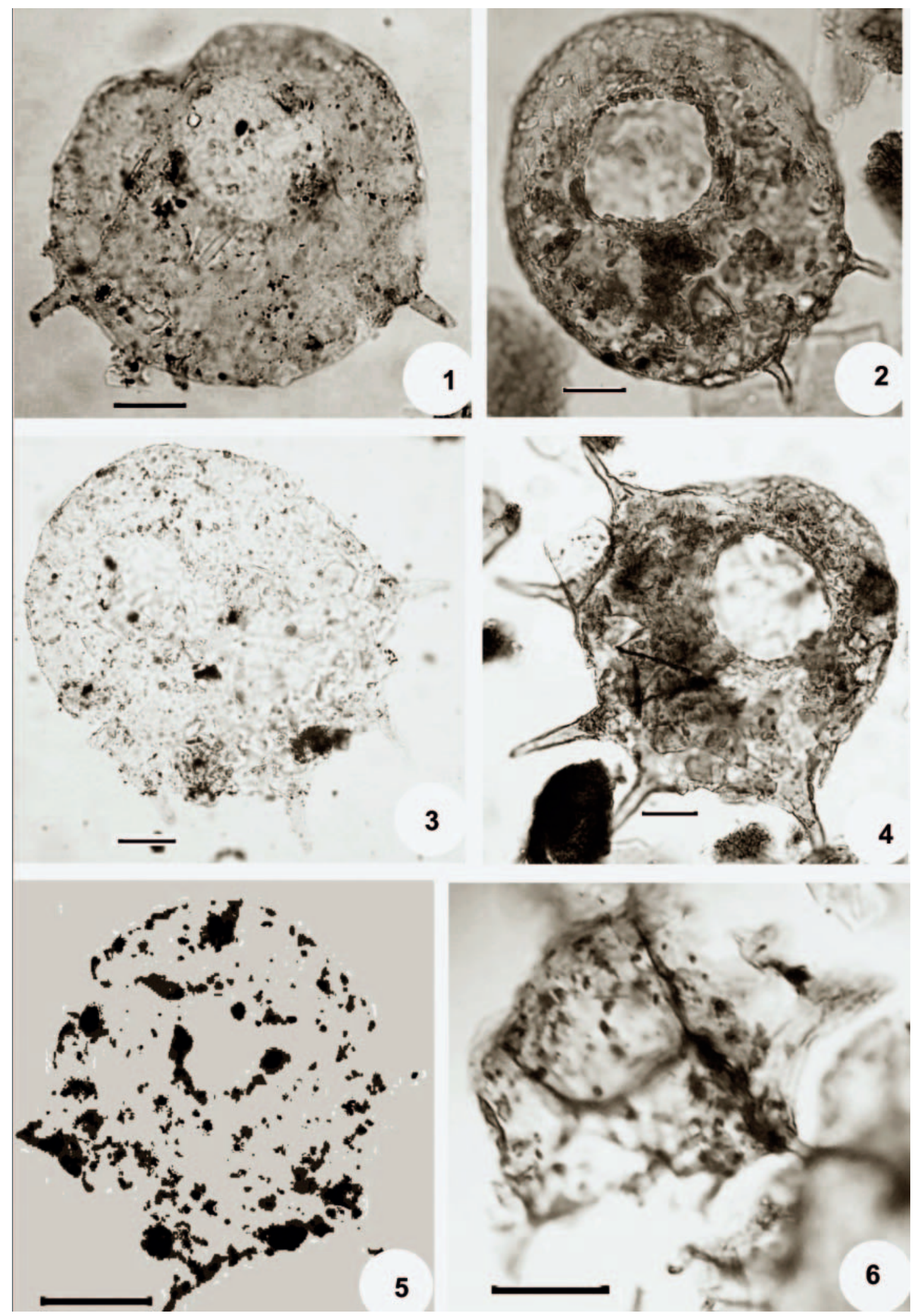

Explanation of Plate 5.

figs 1, 2. Centropyxis aculeata 'aculeata': 1, fossil (U38/3), slide no. 12865A; 2, Recent, source - Sadatal lake, India. figs 3, 4. C. constricta 'spinosa': 3, fossil (W39), slide no. 12865B; 4, Recent, source-Sadatal lake, India. figs 5, 6. ?C. constricta 'spinosa': 5, fossil (P37/3), slide no. 13964; 6, Recent, source - Wadhawana palaeolake ( $\sim 500$ years BP), Gujarat, India. All slides are housed in the Birbal Sahni Institue of Palaeobotany, Lucknow. England Finder coordinates in brackets. Scale is $20 \mu \mathrm{m}$. 

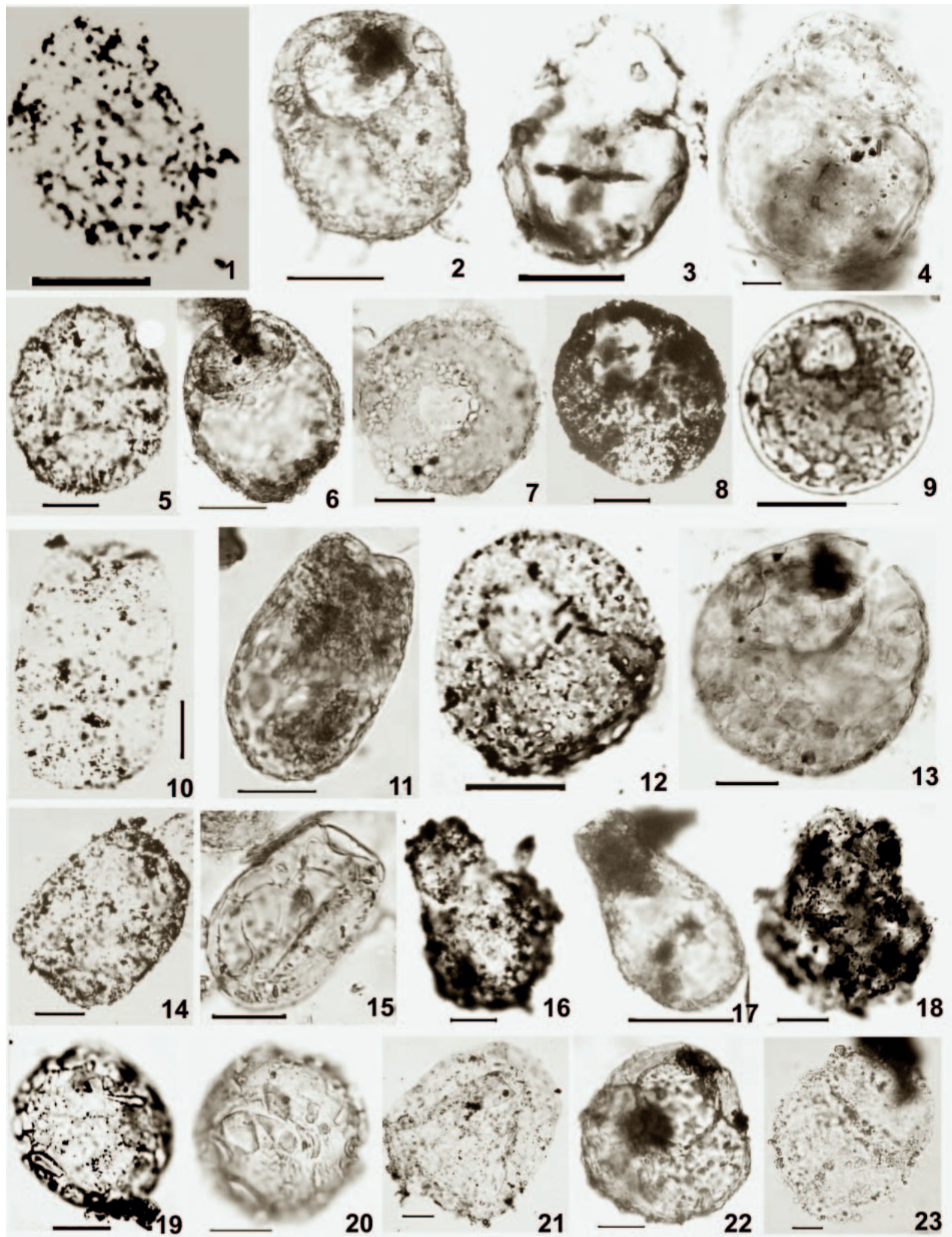

Explanation of Plate 6.

figs 1, 2. cf. Centropyxis constricta 'spinosa': 1, fossil (V34), slide no. 13964; 2, Recent, source - sewage disposal ponds (flowing water), India. figs 3, 4. cf. C. aerophila 'aerophila': 3, fossil (G33/2), slide no. 13961; 4, Recent, source - in association with bryophytes and lichens growing on Mango tree bark, Malihabad, Lucknow, India. figs 5, 6. C. aerophila 'aerophila': 5, fossil (H12/1), slide no. 13957; 6, Recent, source - with bryophytes, lichen (as above). fig. 7. Centropyxis arcelloides (fossil) (J11/4), slide no. 13960. figs 8, 9. Difflugia gramen: 8, fossil (J35/2), slide no. 13966; 9, Recent, source - stream polluted with sewage (flowing throughout the year), Lucknow. figs 10, 11. D. oblonga: 10, fossil (P13/4), slide no. 13959; 11, Recent, source - Sadatal Lake, India. figs 12, 13. D. oviformis: 12, fossil (S23/1), slide no. 13957; 13, Recent, source - Sadatal Lake, India. figs 14, 15. D. penardi: 14, fossil (F32/1), slide no. 13960; 15, Recent, source - Sadatal Lake, India. figs 16, 17. D. pyriformis: 16, fossil (G42 \& G43), slide no. 13962; 17, Recent, source - Sadatal Lake, India. fig. 18. Lagenodifflugia (fossil) (F33/1), slide no. 13957. figs 19, 20. Incerta sp., agglutinated sphere of unknown affinity: 19, fossil (J10/1 \& 10/2), slide no. 13958; 20, Recent, source - sewage drainage system, Lucknow, India. figs 21, 22. cf. Cucurbitella tricuspis: 21, fossil (H45/2), slide no. 13961; 22, Recent, source - Sadatal Lake, India. fig. 23. D. urceolata type (fossil) (V40/1), slide no. 12861b. All slides are housed in the Birbal Sahni Institue of Palaeobotany, Lucknow. England Finder coordinates in brackets. Scale $20 \mu \mathrm{m}$. 

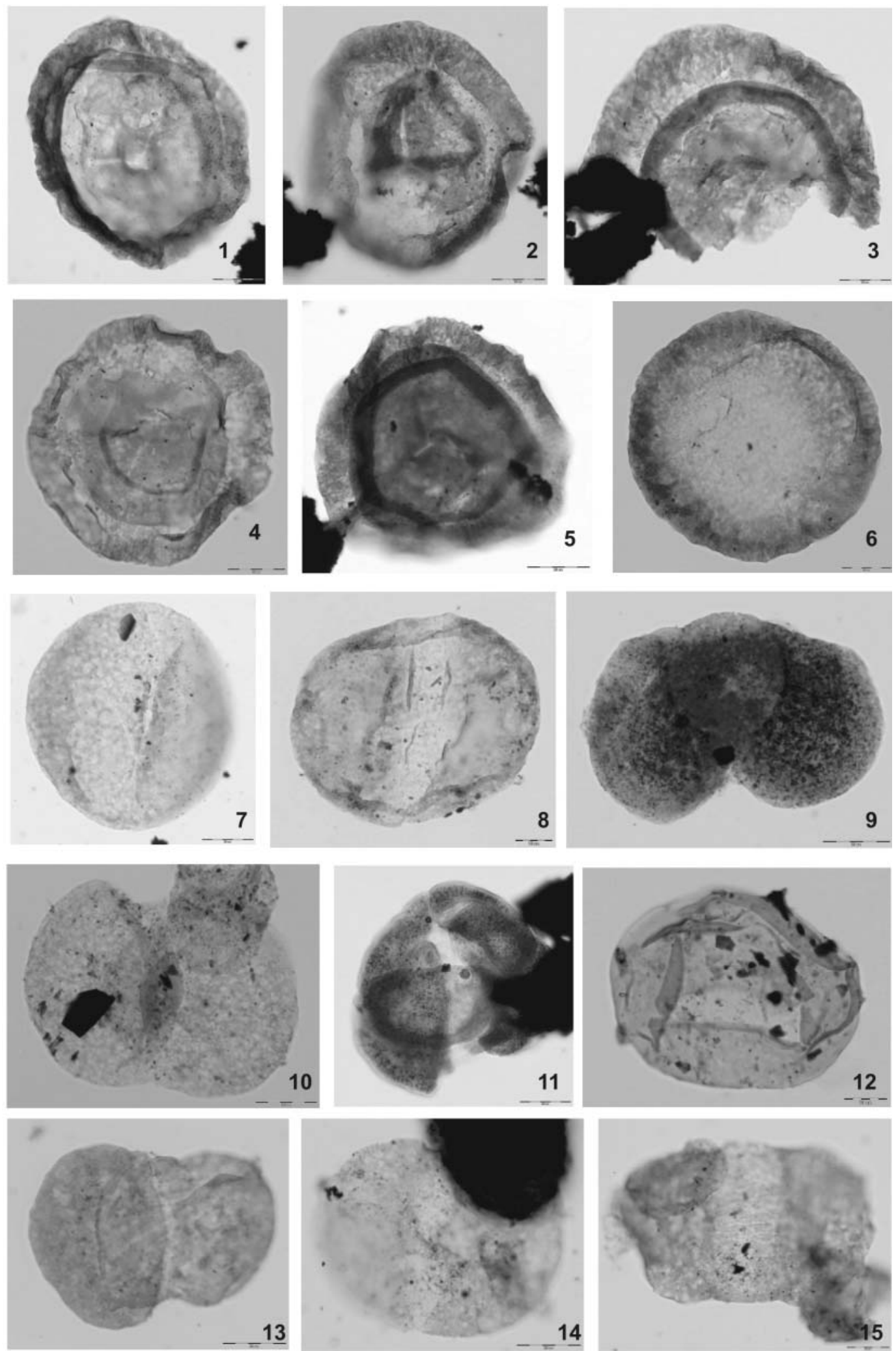

Explanation of Plate 7.

figs 1, 3, 5. Plicatipollenites: 1, (J42), slide no. 12861; 3, (Q42/1), slide no. 12861; 5, (Q40/2), slide no. 12866. figs 2, 4. Barakarites: 2, (K45), slide no. 12861; 4, (Y48/1), slide no. 12862. fig. 6. Parasaccites (K31/1), slide no. 12859. fig. 7. Scheuringipollenites (M43/3), slide no. 12865. fig. 8. Faunipollenites (Q41/3), slide no. 12869. fig. 9. Platysaccus (H35/1), slide no. KR-11-5. fig. 10. Pinuspollenites (E53), slide no. 12869. fig. 11. Corisaccites (F68), slide no. KR 63-A9. fig. 12. Latosporites (G30/2), slide no. 12859. figs 13, 15. Striatopodocarpites: 13, (F36/2), slide no. 12865 A; 15, (S65), slide no. KR-11-Z. fig. 14. Faunipollenites (M40/1), slide no. 12865. All slides are housed in the Birbal Sahni Institue of Palaeobotany, Lucknow. England Finder coordinates in brackets. Scale $20 \mu \mathrm{m}$. 


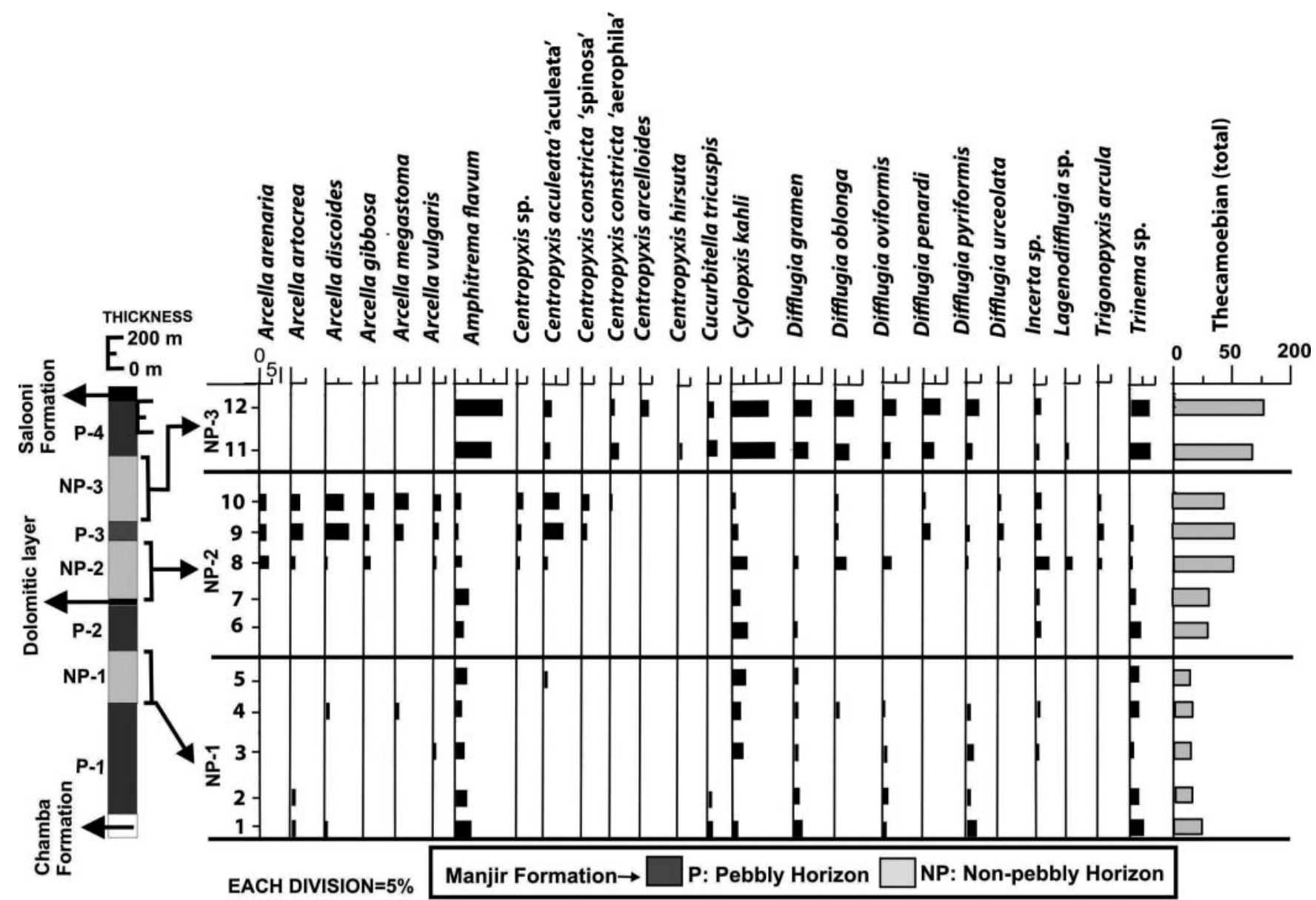

Fig. 2. Thecamoebian spectrum in Non-pebbly Units of the Manjir Formation, Himachal Pradesh, India. Some rare taxa omitted.

with subordinate siltstone and black shale. The thecamoebians show low counts but are dominated by Amphitrema flavum, Trinema sp. ( $\sim 25 \%)$ followed by Difflugia oviformis, D. gramen, D. pyriformis, Cyclopyxis kahli $(6-12 \%)$. The lowest count was of Arcella artocrea and A. discoides.

\section{NP-2}

Separated by pebbly unit P-2, this non-pebbly unit is a black to greyish-black, non-calcareous shale/slate and siltstone with minor pockets of dolomite/dolomitic limestone. The overall thecamoebian count and taxonomic diversity are higher in this non-pebbly unit. The highest percentage occurrence was of Centropyxis aculeata 'aculeata', Arcella artocrea, A. discoides and Cyclopyxis kahli, each ranging from $<5-10 \%$. Other species of Difflugia and Arcella, as shown in Figure 2, constitute $<5 \%$.

\section{NP-3}

This unit is again separated by a pebbly unit (P-3) and is similar to NP-1 with a similar thecamoebian community. The sediment is non-pebbly, non-calcareous, greyish-black slate with occasional siltstone bands. The highest percentage of Cyclopyxis kahli and Amphitrema flavum ranged between 15\% and 19\% in this unit. Other forms, such as centropyxids, Cucurbitella and Difflugia species range between $3 \%$ and $8 \%$. The following thecamoebian taxa were observed and the taxonomic and nomenclatural details are primarily from Medioli et al. (1987; 1999; 2003).

Phylum Protozoa Goldfuss, 1818

Subphylum Sarcodina Schmarda, 1871

Class Rhizopoda von Siebold, 1845

Subclass Lobosa Carpenter, 1861

Order Arcellinida Kent, 1880

Family Amphitremidae Poche, 1913

Genus Amphitrema Archer, 1869

Amphitrema flavum Archer, 1869 (P1. 3, figs 2, 5, 6; P1. 4, figs $1,2)$

Family Arcellidae Ehrenberg, 1832

Genus Arcella Ehrenberg, 1832 Arcella arenaria Greeff, 1866 (Pl. 4, figs 3, 4)

A. artocrea Leidy, 1876 (Pl. 4, figs 5, 6)

A. discoides Ehrenberg, 1843 (Pl. 4, figs 9-12)

A. gibbosa Penard, 1890 (cf. Pl. 4, fig. 15)

A. megastoma Penard, 1923 (Pl. 4, figs 7, 8)

A. vulgaris Ehrenberg, 1832 (Pl. 4, figs 13, 14)

Family Centropyxidae Jung, 1942

Genus Centropyxis Stein, 1857 
Centropyxis aculeata 'aculeata' Reinhardt et al., 1998 (Pl. 5, figs 1,2)

?C. constricta 'spinosa' (Pl. 5, figs 5, 6)

C. arcelloides Penard, 1902 (Pl. 6, fig. 7)

cf. Centropyxis constricta 'spinosa' Reinhardt et al., 1997 (P1. 6, figs 1, 2)

C. constricta 'aerophila' Deflandre, 1929 (Pl. 6, figs 4-6)

?C. constricta 'aerophila' Deflandre, 1929 (Pl. 6, fig. 3)

C. constricta 'spinosa' Ehrenberg, 1843 (Pl. 5, figs 3, 4)

C. hirsuta Deflandre, 1929 (P1. 4, fig. 16)

Family Difflugidae Stein, 1859

Genus Difflugia LeClerc, 1815

Difflugia gramen Penard, 1923 (Pl. 6, figs 8, 9)

D. oblonga Ehrenberg, 1838 (Pl. 6, figs 10, 11)

D. oviformis Cash, 1909 (Pl. 6, figs 12, 13)

D. penardi Hopkinson, 1909 (Pl. 6, figs 14, 15)

D. pyriformis Ehrenberg, 1838 (P1. 6, figs 16, 17)

D. urceolata Carter, 1864 (Pl. 6, fig. 23)

Genus Lagenodifflugia Leidy, 1874

Lagenodifflugia sp. (P1. 6, fig. 18)

Family Hyalospheniidae Schultze, 1877

Genus Cucurbitella Penard, 1902

Cucurbitella tricuspis (Carter) Reinhardt et al., 1998 (P1. 6, figs 21, 22)

Family Trigonopyxidae Loeblich \& Tappan, 1964

Genus Cyclopyxis Deflandre, 1929

Cyclopyxis kahlii (Deflandre, 1929) Bonnet, 1953 (Pl. 4, figs 19, 20)

Genus Trigonopyxis Leidy, 1879

Trigonopyxis arcula Leidy, 1879 (P1. 4, figs 17, 18)

Family Trinematidae Hoogenraad \& Groot, 1940

Genus Trinema Dujardin, 1841

Trinema sp. (Pl. 4, fig. 21)

Incertae sedis

Incerta sp. - agglutinated sphere of unknown affinity (cf. Dalby et al., 2000).

\section{DISCUSSION}

\section{Palaeoecology and depositional environment}

Draganits et al. (2008, pp. 128-129) consider the Manjir Formation 'probably represents glaciomarine debris flow deposits that accumulated during glacial lowstand' and correlated it with other glaciomarine deposits in the Lesser Himalaya described by Frank et al. (1995) and Dipietro \& Pogue (2004). Stephenson et al. (2007) reviewed Early Parmian palaeontological data from Gondwana and concluded that diversity increased from glacial conditions to post-glacial conditions. A similar review of palynological data indicates that a change from monosaccate pollen assemblages associated with fern spores, to more diverse assemblages with common non-taeniate pollen occurs through the deglaciation period in Gondwana (Stephenson, 2008).
During the Early Permian the uplands in Oman witnessed changes from a glacial monosaccate pollen-producing flora to a warmer climate bisaccate pollen-producing flora. A similar trend was also observed in Early Permian Manjir Formation palynomorph assemblages dominated by monosaccate pollen, such as Parasaccites, Plicatipollenites and Barakarites (Pande et al., 2004). Monosaccate pollen dominated the Early Permian Talchir Formation of Peninsular India, which is a well-known glacial deposit (Tiwari \& Tripathi, 1992). Several Early Permian age marine successions of various parts of the Himalayas are dominated by monosaccate pollen assemblages (Srivastava et al., 1987; Upadhyay et al., 1999a, b; Sinha et al., 2004). The dominance of monosaccate pollen flora in the Early Permian has also been observed on other continents and countries of Gondwana, for example: Africa (Falcon, 1975; Anderson, 1977; Utting, 1978); Antarctica (Barret \& Kyle, 1975; Kemp et al., 1977; Kyle \& Schopf, 1982; Masood et al., 1994); Australia (Truswell, 1980); Brazil (Bhardwaj et al., 1976) and India (Lele \& Chandra, 1973; Bhardwaj, 1975; Lele, 1975). Palynomorph assemblages are well known from the Early Permian marine and inter-trappean volcanic sediments across the Himalayan region (Srivastava et al., 1987; Prasad et al., 1989; Singh et al., 1995; Upadhyay et al., 1999a, b; Srivastava \& Bhattacharya, 2000; Sinha et al., 2004). A more or less similar trend is observed in all these palynomorph assemblages.

Late Carboniferous-Early Permian glaciation was widespread over Gondwana and sequences of marine and nonmarine sediments are common in Permo-Carboniferous deposits. Widespread distribution of glacial sediments occurs in South America, Africa, Madagascar, Arabia, India, Antarctica and Australia. During the Early Permian the location of the Chamba Basin would have been around $50-55^{\circ} \mathrm{S}$ latitude, making it a very cold region at that time (Fig. 3). The shale/slate units of the Manjir Formation represent marine tongues formed during deglaciation phases (Draganits et al., 2008). Thus, it is clear that the thecamoebian assemblage reported from the Manjir Formation represent glaciomarine environments.

\section{Transition from marine to terrestrial habitats}

Extant thecamoebians inhabit a wide variety of terrestrial environments, for example, fresh-water bodies such as lakes, ponds and rivers, slightly brackish and estuarine environments, and salt- and fresh-water marshes (Scott et al., 2001; Patterson \& Kumar, 2002). Although there are no known truly marine occurrences of extant thecamoebians, their geological record includes marine environments. Wightman et al. (1994) described agglutinated foraminifera and thecamoebian assemblages from Carboniferous (late Westphalian-Stephanian) cyclothems of the Sydney coal field in Nova Scotia. They defined four foraminiferal and thecamoebian assemblages and concluded that the host sediments were deposited on an extensive coastal platform. The Trochammina and thecamoebian assemblages were found within the upper part of the tidal range, and thecamoebian assemblages dominated by an agglutinated difflugid type were interpreted to indicate fresh-water palaeoenvironments. Scott et al. (2001) mention a few other such reports of pre-Quaternary occurrences of thecamoebians in marginal marine environments.

As discussed earlier, the oldest thecamoebians were described as VSMs from the Neoproterozoic rocks of Grand Canyon, 


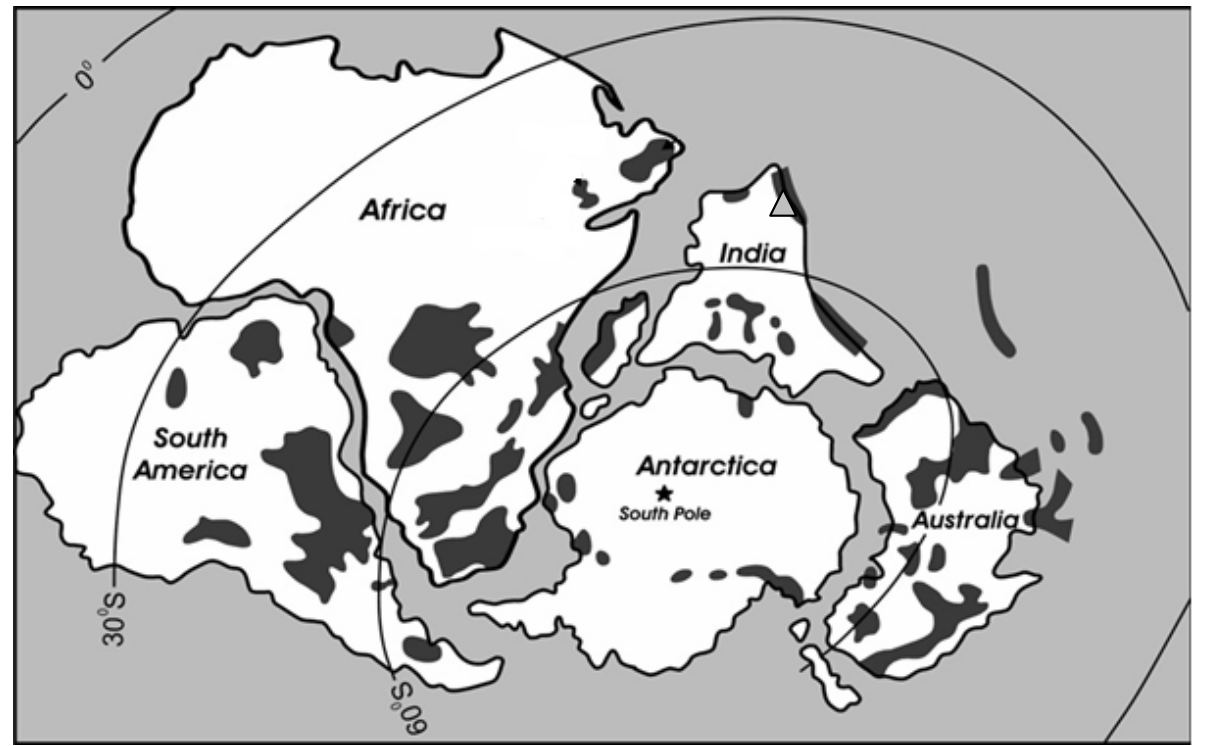

Fig. 3. Palaeogeography of Late Carboniferous-Early Permian Gondwana and distribution of glacigenic deposits (black shading). Location of Chamba Basin indicated by grey triangle. Modified after Bussert \& Schrank (2007).

USA by Porter \& Knoll (2000) and Porter et al. (2003). These VSMs were reported from carbonate nodules in black shales of the Walcott Member (Kwagunt Formation) of the Chuar Group in the Grand Canyon. This stratigraphic unit is a marine deposit because these VSMs occur with several acritarch taxa that are found elsewhere in marine successions. The presence of certain acritarch taxa in the Precambrian sediments does not necessarily indicate marine environments; however, based on many lines of geological evidence, Porter \& Knoll (2000, p. 364) conclude that, 'The abundant VSMs found in the upper Walcott member appear to have accumulated in a quiet subtidal marine environment characterized by high rates of organic carbon burial'. This discussion clearly demonstrates that the earliest thecamoebians inhabited marine environments. The present report of early Permian marine thecamoebians from the Himalayas supports the view that this group of protists inhabited shallow-marine environments from their origins in the Neoproterozoic until at least Early Permian times.

Although extant testate amoebae are predominantly terrestrial, they are not totally absent from marginal marine environments, and members of both Testacealobosa and Testaceafilosa inhabit tidal pools and beach sands (Sudzuki, 1979; Porter \& Knoll, 2000). There are a few reports of thecamoebians from deep sediments of fjords of British Columbia (Patterson et al., 2000; Kumar \& Patterson, 2002) but they are mostly allochthonous, transported from land by streams and rivers. Thus, it is concluded from the above discussion that thecamoebians did inhabit subtidal marine environments during their early history (Neoproterozoic to at least Early Permian) but subsequently their habitat moved primarily to terrestrial environments and the closest they now inhabit to a marine environment is coastal marshes and other marginally brackish environments.

\section{ACKNOWLEGEMENTS}

Kumar thanks King Fahd University of Petroleum and Minerals, Dhahran, Saudi Arabia, and Farooqui and Jha thank the
Director, Birbal Sahni Institute of Palaeobotany, Lucknow, India for permission to publish this paper. The authors also thank Profs Franco S. Medioli and David B. Scott of Dalhousie University, Canada for their constructive comments which have improved this paper. Dr Lameed Babalola of King Fahd University of Petroleum and Minerals kindly redrafted Figures 2 and 3 .

Manuscript received 8 November 2010

Manuscript accepted 24 February 2011

Scientific editing by Alan Lord

\section{REFERENCES}

Anderson, J.M. 1977. The biostratigraphy of the Permian and Triassicpart 3. A review of Gondwana Permian palynology with particular reference to the northern Karoo Basin, South Africa. Memoir Botanical Survey of South Africa, 41: 1-67.

Barret, P.J. \& Kyle, R.A. 1975. The Early Permian glacial of South Victoria Land and Darwin Mountains, Antarctica. In: Campbell, K.S. (Ed.), Gondwana Geology. Australian National University Press, Canberra, pp. 333-346.

Bassi, D.E., Fugagnoli, A., Posenato, R. \& Scott, D.B. 2008. Testate amoebae from the Early Jurassic of the western Tethys, northeast Italy. Palaeontology, 51: 1335-1339.

Beyens, L. \& Meisterfeld, R. 2002. Protozoa: testate amoebae. In: Smol, J.P., Birks, J.B. \& Last, W.M. et al. (Eds), Tracking Environmental Change Using Lake Sediments. Springer, Netherlands, pp. 121-153.

Bhardwaj, D.C. 1975. Palynology in biostratigraphy and palaeoecology of Indian Lower Gondwana Formations. Palaeobotanist, 22: 150-157.

Bhardwaj, D.C., Kar, R.K. \& Navale, G.K.B. 1976. Palynostratigraphy of Lower Gondwana deposits in Parana and Maranhao basins, Brazil. Biological Memoir, 1: 56-103.

Boeuf, O. \& Gilbert, D. 1997. Présence de Thécamoebiens du genre Trinema au Pliocène supérieur, découverte à Chilhac (Haute-Loire, France). Comptes rendus hebdomadaires des Séances de l'Academie des Sciences, Paris, 325: 623-627.

Boudreau, R.E.A., Galloway, J., Patterson, R.E., Kumar, A. \& Michel, F.A. 2005. A paleolimnological record of Holocene climate and environmental change in the Temagami region, northeastern Ontario. Journal of Paleolimnology, 33: 445-461. 
Bradley, W.H. 1931. Origin and the microfossils of the oil shale of the Green River Formation of Colorado and Utah. United States Geological Survey Professional Paper, 168: 1-58.

Bussert, R. \& Schrank, E. 2007. Palynological evidence for a latest Carboniferous-Early Permian glaciation in Northern Ethiopia. Journal of African Earth Science, 49: 201-210.

Carter, H.J. 1856. Notes on the fresh water Infusoria of the Island of Bombay. No. 1. Organization. Annals and Magazine of Natural History, Series 2, 18: 221-249.

Carter, H.J. 1864. On fresh water Rhizopoda of England and India. Annals and Magazine of Natural History, series 3, 13: 18-39.

Charman, D., Hendon, D. \& Woodland, W. 2000. The identification of peatland testate amoebae. Quaternary Research Association Technical Guide, 9: 1-147.

Charman, D., Roe, H.M. \& Gehrels, W.R. 2002. Modern distribution of saltmarsh testate amoebae: regional variability of zonation and response to environmental variables. Journal of Quaternary Science, 17: 387-409.

Dalby, A.P., Kumar, A., Moore, J.M. \& Patterson, R.T. 2000. Preliminary survey of Arcellaceans (Thecamoebians) as limnological indicators in tropical Lake Sentani, Irian Jaya, Indonesia. Journal of Foraminiferal Research, 30: 135-142.

DiPietro, J.A. \& Pogue, K.R. 2004. Tectonostratigraphic subdivisions of the Himalaya: a view from the west. Tectonics, 23. DOI: 10.1029/ 2003 TC001554.

Draganits, E., Schlaf, J., Grasemann, B. \& Argles, T. 2008. Giant submarine landslide grooves in the Neoproterozoic/Lower Cambrian Phe Formation, northwest Himalaya: Mechanisms of formation and paleogeographic implications. Sedimentary Geology, 205: 126-141.

Erdtman, G. 1943. An Introduction to pollen analysis. Chronica Botanica Co, Waltham, Mass, US.

Falcon, R.M.S. 1975. Palynostratigraphy of the Karoo Sequences in the central Sebungwe District, Mid Zambesi Basin, Rhodesia. Palaeontologica Africana, 18: 1-29.

Farooqui, A. \& Gaur, A.S. 2007. Arcellaceans and pollen/spores of a late Harappan settlement near Porbandar, west coast of India: implications for palaeoecology and environmental monitoring. Current Science, 92: 992-998.

Farooqui, A., Kumar, A., Jha, N., Pande, A.C. \& Bhattacharya, D.D. 2010. A Thecamoebian Assemblage from the Manjir Formation (Early Permian) of Northwest Himalaya, India. e-Journal Earth Science India, 3: 146-153.

Foissner, W. \& Schiller, W. 2001. Stable for 15 million years: scanning electron microscope investigation of Miocene euglyphid thecamoebians from Germany, with description of new genus Scutiglypha. European Journal of Protistology, 37: 167-180.

Frank, W., Grasemann, B., Guntli, P. \& Miller, C. 1995. Geological map of the Kishtwar-Chamba-Kulu Region (NW Himalaya, India). Jahrbuch der Geologisches Bundesanstalt, 138: 299-308.

Frenguelli, G. 1933. Tecamoebiani e Diatomee nel Miocene del Neuquen (Patagonia Settentrionale). Bolletino della Società Geologica Italiana, 52: 33-43.

Hoogenraad, H.R. \& Groot, A.A. 1940. Moosbewhnende thekamoebe rhizopoden von Java und Sumatra. Treubia, 17: 209-256.

Hoogenraad, H.R. \& Groot, A.A. 1946. Thekamoebe sphagnumrhizopoden van Buitenzorg (Java). Biologische Jaarboek, Dodonea (Gent), 13: $112-126$.

Kemp, E.M., Balme, B.E., Helby, R.J., Kyle, R.A., Playford, G. \& Price, P.L. 1977. Carboniferous and Permian palynostratigraphy in Australia and Antarctica: A review. Bureau of Mines and Mineral Resources Journal of Australian Geology and Geophysics, 2: 177-208.

Kövàry, J. 1956. Thekamöbak (Testaceak) a magyarorszagy alsopannoniai koru üled ekekböl. Földtani Közlöny, 86: 266-273.

Kumar, A. 2011. Acid-resistant Cretaceous thecamoebian tests from the Arabian Peninsula: a suggestion for study of agglutinated rhizopods in palynological slides. Journal of Micropalaeontology, 30: 1-5.

Kumar, A. \& Dalby, A.P. 1998. Identification key for Holocene lacustrine Arcellacean (thecamoebian) taxa. Palaeontologia Electronica, 1: 1-39.
Kumar, A. \& Patterson, R.T. 2002. Dinoflagellate cyst assemblages from Effingham Inlet, Vancouver Island, British Columbia, Canada. Palaeogeography, Paleoclimatology, Palaeoecology, 180: 187-206.

Kyle, R.A. \& Schopf, J.M. 1982. Permian and Triassic palynostratigraphy of the Victoria Group, Trans Antarctic Mountains. In: Craddock, A. (Ed.), Antarctic Geoscience. University of Wisconsin Press, Madison, pp. 649-659.

Lele, K.M. 1975. Studies in the Talchir flora of India - Early and Late Talchir microflora from the West Bokaro coalfield, Bihar. Palaeobotanist, 22: 219-235.

Lele, K.M. \& Chandra, A. 1973. Studies in the Talchir flora of India 8. Miospores from the Talchir Boulder Bed and overlying needle shales in the Johilla Coalfield, M. P., India. Palaeobotanist, 20: 9-47.

Martin-González, A., Wierzchos, J., Gutiérrez, J.C., Alonso, J. \& Ascaso, C. 2009. Microbial Cretaceous park: biodiversity of microbial fossils entrapped in amber. Naturwissenschaften, 96: 551-564.

Masood, K.R., Taylor, T.N., Horner, T. \& Taylor, E.L. 1994. Palynology of the Mackellar Formation (Beacon Supergroup) of East Antarctica. Review of Palaeobotany and Palynology, 83: 329-337.

Medioli, F.S. \& Scott, D.B. 1983. Holocene Arcellacea (Thecamoebians) from Eastern Canada. Cushman Foundation for Foraminiferal Research, Special Publication, 21: 1-63.

Medioli, F.S. \& Scott, D.B. 1988. Lacustrine thecamoebians (mainly Arcellaceans) as potential tools for palaeolimnological interpretations. Palaeogeography, Palaeoeclimatology, Palaeoecology, 62: 361386.

Medioli, F.S., Scott, D.B. \& Abbot, B.H. 1987. A case study of protozoan interclonal variability: taxonomic implications. Journal of Foraminiferal Research, 17: 28-47.

Medioli, F.S., Scott, D.B., Collins, E.S. \& Wall, J.H. 1990a. Thecamoebians from the Early Cretaceous deposits of Ruby Creek, Alberta (Canada). In: Hemleben, C., Kaminski, M.A., Kuhnt, W. \& Scott, D.B. (Eds), Proceedings of the NATO Advanced Study Institute on Paleoecology, biostratigraphy, paleoceanography and taxonomy of agglutinated foraminifera. NATO ASI Series C: Mathematical and Physical Sciences, 327. D. Reidel, Dordrecht, 793-812.

Medioli, F.S., Scott, D.B., Collins, E.S. \& Wall, J.H.. 1990b. Fossil thecamoebians: present status and prospects for the future. In: Hemleben, C., Kaminski, M.A., Kuhnt, W. \& Scott, D.B. (Eds), Proceedings of the NATO Advanced Study Institute on Paleoecology, biostratigraphy, paleoceanography and taxonomy of agglutinated foraminifera. NATO ASI Series C: Mathematical and Physical Sciences, 327. D. Reidel, Dordrecht, 813-839.

Medioli, F.S., Scott, D.B., Collins, E., Asioli, A. \& Reinhardt, A. 1999 The thecamoebian bibliography. Palaeontologia Electronica, 3: 1-161 (http://palaeo-electronica.org/1999_1/biblio/issue1_99.htm).

Medioli, F.S., Bonnet, L., Scott, D.B. \& Medioli, B.E.. 2003. The thecamoebian bibliography (2nd edn). Palaeontologia Electronica, 6: 1-107 (http://palaeo-electronica.org/2003_1/biblio/issue1_03.htm).

Pande, A.C., Bhattacharya, D.D., Jha, N., Misra, R.S. \& Chandra, S. 2004. Discovery of Early Permian palynomorphs from the Manjir Formation, Chamba District, Himachal Pradesh. Journal of the Geological Society of India, 63: 665-669.

Patterson, R.T. \& Kumar, A. 2000. Use of Arcellacea (Thecamoebians) to Gauge Levels of Contamination and Remediation in Industrially Polluted Lakes. Environmental Micropaleontology, 15: 257-278.

Patterson, R.T. \& Kumar, A. 2002. A review of current testate rhizopod (thecamoebian) research in Canada. Palaeogeography, Palaeoclimatology, Palaeoecology, 180: 225-251.

Patterson, R.T., Hutchinson, I., Guilbault, J.-P. \& Clague, J.J. 2000. A comparison of vertical zonation of diatom, foraminifera, and macrophyte assemblages in a coastal marsh: implications for greater paleosea level resolution. Micropaleontology, 46: 229-244.

Poinar, G.O., Waggoner, B.M. \& Bauer, U-C. 1993. Terrestrial softbodied protists and other micro-organisms in Triassic amber. Science, 259: $222-224$ 
Porter, S.A. \& Knoll, A. 2000. Testate amoebae in the Neoproterozoic Era: evidence from vase-shaped microfossils in the Chuar Group, Grand Canyon. Paleobiology, 26: 360-385.

Porter, S., Meisterfeld, R. \& Knoll, A. 2003. Vase-shaped microfossils from the Neoproterozoic Char Group, Grand Canyon: a classification guided by modern testate amoebae. Journal of Paleontology, 77: 409-429.

Prasad, B., Dey, A.K., Gogoi, P.K. \& Maithani, A.K. 1989. Early Permian plant microfossils from the intertrappean beds of Abor Volcanics, Arunachal Pradesh, India. Journal of the Geological Society of India, 34: 83-88.

Rattan, S.S. 1973. Stratigraphy and sedimentation of the Chamba area, western Himachal Pradesh. Himalayan Geology, 3: 231-248.

Reinhardt, E.G., Dalby, A., Kumar, A. \& Patterson, R.T. 1998. Utility of arcellacean phenotypic variants as pollution indicators in mine tailing contaminated lakes near Cobalt, Ontario, Canada. Micropaleontology, 43: 131-148.

Riveiros, N.V., Babalola, A.O., Boudreau, R.E.A., Patterson, R.T., Roe, H.M. \& Doherty, C. 2007. Modern distribution of salt marsh foraminifera and thecamoebians in the Seymour-Belize Inlet Complex, British Columbia, Canada. Marine Geology, 242: 39-63.

Roe, H. \& Patterson, R.T. 2006. Distribution of Thecamoebians (Testate Amoebae) in small lakes and ponds, Barbados, West Indies. Journal of Foraminiferal Research, 36: 116-134.

Roe, H.M., Charman, D. \& Gehrels, W.R. 2002. Fossil testate amoebae in coastal deposits in the UK: implications for studies of sea-level change. Journal of Quaternary Science, 17: 411-429.

Schiller, W. 1997. Kieselige Thekamöben aus der Miozänen Kieselgur von Beuern/Vogelsberg im Vergleich mit rezentem Material von Borneo (Malaysia). Courier Forschungsinstitut-Institut Senckenberg, 201: 385-392.

Schiller, W. 1998. Kieselige mikrofossilien aus dem Unter-Oligozän von Sieblos/Rhön. Geologische Abhandlungen, Hessen, 104: 173-199.

Schiller, W. 1999. Kieselige Thekamöben aus del Mittel-Eozän des Eckfelder Maares in der Eifel. Mainzer Naturwissenschaftliches Archiv, 37: 55-62.

Schmidt, A.R., von, Eynatten, H. \& Agreich, M. 2001. The Mesozoic amber of Schliersee (southern Germany) is Cretaceous in age. Cretaceous Research, 22: 55-62.

Schmidt, A.R., Schönborn, W. \& Schäfer, U. 2004. Diverse fossil amoebae in German Mesozoic amber. Palaeontology, 47: 185-107.

Schönborn, W., Dörfelt, H., Foissner, W., Krienitz, L. \& Schäfer, U. 1999. A fossilized microcenosis in Triassic amber. Journal of Eucaryotic Microbiology, 46: 571-584.

Scott, D., Medioli, F.S. \& Schafer, C.T. 2001. Monitoring Coastal Envirobnments Using Foraminifera and Thecamoebian Indicators. Cambridge University Press, NY, 177pp.

Scott, D.B., Medioli, F.S. \& Braund, R. 2003. Foraminifera from the Cambrian of Nova Scotia: The oldest multichambered foraminifera. Micropaleontology, 49: 109-126.

Sehgal, M.N. 1965. Systematic geological mapping in parts of Chamba district, H. P. Unpublished Geological Survey of India Report for F.S. 1964-1965

Singh, T., Tiwari, R.S., Vijaya \& Awatar, R. 1995. Stratigraphy and palynology of Carboniferous-Permian-Triassic succession in Spiti Valley, Tethys Himalaya, India. Journal of the Palaeontological Society of India, 40: 55-76.

Sinha, A.K., Jha, N. \& Upadhyay, R. 2004. Additional information on palynological dating of Chhongtash Formation in eastern Karakoram and its palaeogeographical significance. Current Science, 86: 719-723.

Srivastava, S.C. \& Bhattacharya, A.P. 1998. Early Permian microfossils in faunal coal balls from Arunachal Pradesh, India - phytogeographic and palaeoenvironmental significance. Geophytology, 26: 75-82.

Srivastava, S.C. \& Bhattacharya, A.P. 2000. Palynology in stratigraphy of Lesser Himalayan sedimentary sequences from Arunachal Pradesh, India. Palaeobotanist, 49: 371-383.
Srivastava, S.C., Prakash, A. \& Singh, T. 1987. Permian palynofossils from the eastern Himalaya and their genetic relationship. Palaeobotanist, 36: 326-338.

Stephenson, M.H. 2008. A review of palynostratigraphy of Gondwana Late Carboniferous to Early Permian glacigene successions. Geological Society of America Special Paper, 441: 1-13.

Stephenson, M.H., Angiolini, L. \& Leng, M.J. 2007. The Early Permian fossil record of Gondwana and its relationship to deglaciation: a review. In: Williams, M., Haywood, A.M., Gregory, F.J. \& Schmidt, D.N. (Eds), Deep-Time Perspectives on Climate Change: Marrying the Signal from Computer Models and Biological Proxies. The Micropalaeontological Society, Special PublicationsLondon, 103-122.

Sudzuki, M. 1979. Marine interstitial testacea from Plau Pinang, Malaysia. Anot. Zoology, Japan, 52: 50-53.

Tiwari, R.S. \& Tripathi, A. 1992. Marker assemblage zones of spore and pollen species through the Gondwana Paleozoic and Mesozoic sequence in India. Palaeobotanist, 40: 194-236.

Truswell, E.M. 1980. Permo-Carboniferous palynology of Gondwanaland: Progress and problems in the decade of 1980: Bureau of Minera and Minerals Resources. Journal of Australian Geology and Geophysics, 5: 95-111.

Upadhyay, R., Chandra, R., Rai, H., Jha, N., Chandra, S., Kar, R.K. \& Sinha, A.K. 1999a. A first find of Early Permian Lower Gondwana plant remains and palynomorphsfrom the Chhongtash Formation (Upper Shyok valley), eastern Karakoram, India. Palaeobotanist, 48: 7-18.

Upadhyay, R., Chandra, R., Sinha, A., Kar, R.K., Chandra, S., Jha, N. \& Rai, H. 1999b. Discovery of Gondwana plant fossils and palynomorphs of Late Asselian (Early Permian) age in the Karakoram Block. Terra Nova, 11: 278-283.

Utting, J. 1978. Lower Karoo pollen and spore assemblages from the coal measures and underlying sediments of the Siankondobo Coalfield, Mid Zambezi Valley, Zambia. Palynology, 2: 53-68.

van Hengstum, P.J., Reinhardt, E.G., Medioli, F.S. \& Gröcke, D.R. 2007. Exceptionally preserved late Albian (Cretaceous) Arcellaceans (Thecamoebians) from the Dakota Formation near Lincoln, Nebraska, USA. Journal of Foraminiferal Research, 37: 300-308.

van Oye, P. 1949. Rhizopodes de Java. Bijdragen tot de Dierkunde, 28: 327-352.

Vasicek, M. \& Ruzicka, B. 1957. Namurian Thecamoebina from the Ostraxa-Karxina coal district. Sbornik Naradniho Museav Praze, Reda B, Prirodni Vedy Acta Musei Nationalis Pragae. Series B, Historia Naturalis, 13: 333-340.

Waggoner, B.M. 1996a. The first fossil cyphoderiid testate amoeba in Dominican Republic amber (Eocene-Oligocene). Paleobios, 17: $17-19$.

Waggoner, B.M. 1996b. Bacteria and protists from Middle Cretaceous amber of Ellsworth County, Kansas. Paleobios, 17: 20-26.

Wightman, W.G., Scott, D.B., Medioli, F.S. \& Gibling, M.R. 1994. Agglutinated foraminifera and thecamoebians from the Late Carboniferous Sydney Coalfield, Nova Scotia: Paleoecology, Paleoenvironments and Paleogeographical implications. In Calder, J.H. \& Gibling, M.R. (Eds) The Euroamerican coal province; controls on tropical peat accumulation in the Paleozoic. Palaeogeography, Palaeoclimatology, Palaeoecology, 106: 187-202.

Wolf, M. 1995. Verkieste Amöben in Steinkohlen aus dem Ruhrgebiet erster Nachweis von Arcella Ehrenberg im Paläozoikum. Paläontologisches Zeitschrift, 69: 1-6.

Woodland, W.A., Charman, D.J. \& Sims, P.C. 1998. Quantitative estimates of watertables and soil moisture in Holocene peatlands from testate amoebae. The Holocene, 8: 261-273. 


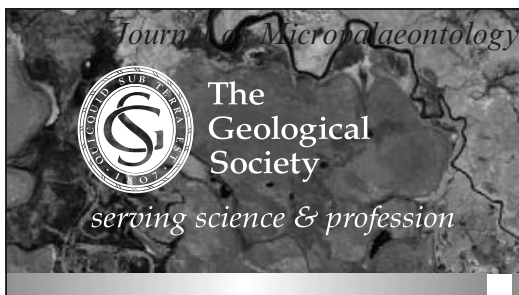

From the Geological Society Publishing House

For full details see the Online Bookshop: www geolsoc.org. uk/bookshop

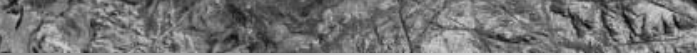

NEW

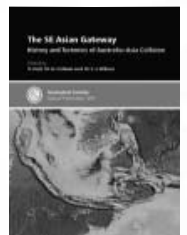

-ISBN: 978-1-86239-329-5 -July 2011 -pages tbc $\bullet$ Hardback

-Prices:

List: tbc

GSL: tbc

Other qualifying societies: tbc

(Cat no tbc)

Online bookshop code: SP355
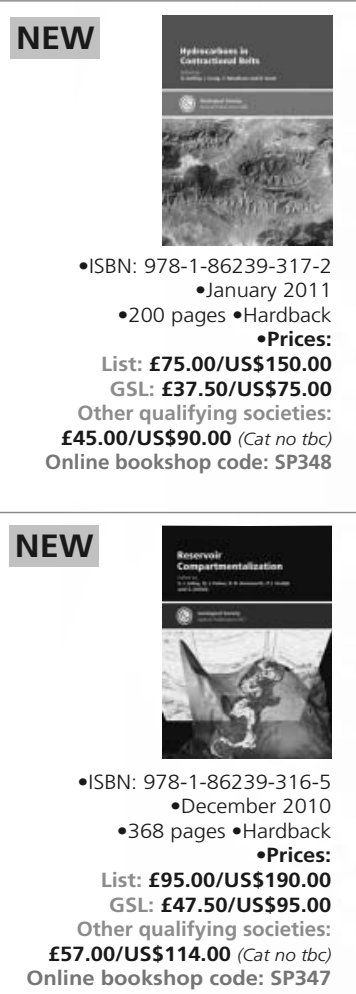

\section{NEW}

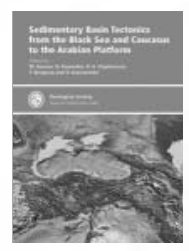

-ISBN: 978-1-86239-308-0 - September 2010

- 512 pages $\bullet$ Hardback

-Prices:

List: $\mathbf{f 1 0 0 . 0 0 / U S \$ 2 0 0 . 0 0}$

GSL: $\mathbf{f 5 0 . 0 0 / U S \$ 1 0 0 . 0 0}$

Other qualifying societies: $\mathbf{f 6 0 . 0 0 / U S \$ 1 2 0 . 0 0 ~ ( C a t ~ n o ~ 1 1 1 0 ) ~}$ Online bookshop code: SP340

Orggr from:

whin.geolsoc.org.uk/bookshop

\section{- Special Publication 355}

\section{The SE Asian Gateway: History and Tectonics of the Australia-Asia collision}

Edited by R. Hall, M. Cottam and M. E. J. Wilson

Collision between Australia and SE Asia began in the Early Miocene and reduced the former wide ocean between them to a complex passage which connects the Pacific and Indian Oceans. Today, the Indonesian Throughflow passes through this gateway and plays an important role in global thermohaline flow, and the region around it contains the maximum global diversity for many marine and terrestrial organisms. Reconstruction of this geologically complex region is essential for understanding its role in oceanic and atmospheric circulation, climate impacts, and the origin of its biodiversity.

The papers in this volume discuss the Palaeozoic to Cenozoic geological background to Australia and SE Asia collision, and provide the background for accounts of the modern Indonesian Throughflow, oceanographic changes since the Neogene, and aspects of the region's climate history.

\section{- Special Publication 348}

\section{Hydrocarbons in Contractional Belts}

Edited by G. P. Goffey, J. Craig, T. Needham and R. Scott

Onshore fold-thrust belts are commonly perceived as 'difficult' places to explore for hydrocarbons and are therefore often avoided. However, these belts host large oil and gas fields and so these barriers to effective exploration mean that substantial unexploited resources may remain. Over time, evaluation techniques have improved. It is possible in certain circumstances to achieve good 3D seismic data. Structural restoration techniques have moved into the 3D domain and increasingly sophisticated palaeo-thermal indicators allow better modelling of burial and uplift evolution of source and reservoirs. Awareness of the influence of pre-thrust structure and stratigraphy and of hybrid thick and thin-skinned deformation styles is augmenting the simplistic geometric models employed in earlier exploration. But progress is a slow, expensive and iterative process. Industry and academia need to collaborate in order to develop and continually improve the necessary understanding of subsurface geometries, reservoir and charge evolution and timing; this publication offers papers on specific techniques, outcrop and field case studies.

\section{- Special Publication 347}

\section{Reservoir Compartmentalization}

Edited by S. J. Jolley, Q. J. Fisher, R. B. Ainsworth, P. J. Vrolijk and S. Delisle

Reservoir compartmentalization, the segregation of a petroleum accumulation into a number of individual fluid/pressure compartments, controls the volume of moveable oil or gas that might be connected to any given well drilled in a field, and consequently impacts on reserves 'booking' and operational profitability. This is a general feature of modern exploration and production portfolios, and has driven major developments in geoscience, engineering and related technology. Given that compartmentalization is a consequence of many factors, an integrated subsurface approach is required to better understand and predict compartmentalization behaviour, and to minimize the risk of it occurring unexpectedly. This volume reviews our current understanding and ability to model compartmentalization. It highlights the necessity for effective specialist discipline integration, and the value of learning from operational experience in: detection and monitoring of compartmentalization; stratigraphic and mixed-mode compartmentalization; and fault-dominated compartmentalization.

\section{- Special Publication 340}

\section{Sedimentary Basin Tectonics from the Black Sea and Caucasus to the Arabian Platform}

Edited by M. Sosson, N. Kaymakci, R. A. Stephenson, F. Bergerat and V. Starostenk

This wide area of the Alpine-Himalayan belt evolved through a series of tectonic events related to the opening and closure of the Tethys Ocean. In doing so it produced the largest mountain belt of the world, which extends from the Atlantic to the Pacific oceans. The basins associated with this belt contain invaluable information related to mountain building processes and are the locus of rich hydrocarbon accumulations. However, knowledge about the geological evolution of the region is limited compared to what they offer. This has been mainly due to the difficulty and inaccessibility of cross-country studies. This Special Publication is dedicated to the part of the Alpine-Himalayan belt running from Bulgaria to Armenia, and from Ukraine to the Arabian Platform. It includes twenty multidisciplinary studies covering topics in structural geology/tectonics; geophysics; geochemistry; palaeontology; petrography; sedimentology; stratigraphy; and subsidence and lithospheric modelling. This volume reports results obtained during the MEBE (Middle East Basin Evolution) Programme and related projects in the circum Black Sea and periArabian regions.

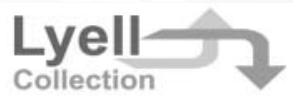

The Geological Society's Lyell Collection: journals, Special Publications and books online. For more information visit www.geolsoc.org.uk/LyellCollection 